\title{
Exploring Forms of Communication for Disseminating Career Guidance Services to Potential University Students
}

\author{
Uleanya M. O. ${ }^{1}$, Uleanya C. ${ }^{2, *}$, Naidoo G. ${ }^{1}$, Rugbeer Y. ${ }^{1}$ \\ ${ }^{1}$ Department of Communication Science, University of Zululand, KwaZulu-Natal, South Africa \\ ${ }^{2}$ Department of Education Leadership and Management, University of Johannesburg, Gauteng, South Africa
}

Received August 8, 2020; Revised August 31, 2020; Accepted October 19, 2020

\section{Cite This Paper in the following Citation Styles}

(a): [1] Uleanya, M.O., Uleanya, C., Naidoo, G., Rugbeer, Y. , "Exploring Forms of Communication for Disseminating Career Guidance Services to Potential University Students, "Universal Journal of Educational Research, Vol. 8, No. 11B, pp. 6048 - 6060, 2020. DOI: 10.13189/ujer.2020.082241.

(b): Uleanya, M.O., Uleanya, C., Naidoo, G., Rugbeer, Y. (2020). Exploring Forms of Communication for Disseminating Career Guidance Services to Potential University Students. Universal Journal of Educational Research, 8(11B), 6048 6060. DOI: 10.13189/ujer.2020.082241.

Copyright $(2020$ by authors, all rights reserved. Authors agree that this article remains permanently open access under the terms of the Creative Commons Attribution License 4.0 International License

\begin{abstract}
Making career choices is crucial to students in all endeavours. However, such decision seems to be difficult and problematic for many students. The reason for such difficulty can be attributed to the way and manner career choices are communicated to students, consequently, this has affected the enthusiasm, learning abilities and academic performances of students. Hence, this study explored various forms of communication for disseminating career guidance services to potential university students. Quantitative method was adopted for the study. Purposive and random sampling was employed in selecting two South African universities and the respondents of the study respectively. The study sample was 374 first year students. A self-designed questionnaire was administered to the selected respondents. The collected data were analysed using Moonstat. The findings of the study following the analysed data show that friends, internet, career seminars, career workshops, university open day, television are various ways by which career information is being communicated to students in the two selected South African universities. However, radio, newspaper and SMS are other media that can be explored. The study recommends amongst others that universities should advertise their courses through various forms of communication to the potential, prospective university students so as to reduce doubts and transfer from one course to another in their first year of study. This is
\end{abstract}

envisaged to help students overcome their challenges in making career choices, consequently, enhance their learning abilities and academic performances.

Keywords Career Choice, Communication, First Year Students, South African Universities

\section{Introduction}

Communication begins with the screaming of a 'new-born child', which is concrete evidence that the child is alive. Arens, et. al. [1] agree that from human first cry at birth, survival depends on their ability to inform others or persuade them to act. Communication serves as a tool which is used in our daily activities of life and it is also used to express our feelings and views towards one another. According to Chatterjee [2], it is important that human communicate to express and try to understand one another's responses either by spoken words, written words or through non-verbal communication. McLaughlin [3] also indicates that man cannot succeed or flourish on his own particular thought; he needs another member of society to complement his thoughts. Communication contributes to every decision made, including career-based ones. Therefore, when engaging in this process, one needs 
to seek advice and express oneself clearly and concisely especially when it comes to career choices. Furthermore, career choice is an aspect of an individual's life which is very important, and has the ability to contribute positively or negatively towards one's future. Proper communication is therefore needed to assist one in making proper decisions when it comes to selecting the correct career path. According to Farheen and Saba [4], career choice is a process of choosing a profession or occupation which designs one's future life/lifestyle. Greenhaus [5] defines career choice as the process of making career decisions about pursuing a job or career, which will eventually bring changes to the occupational fields. Natalie [6] adds that career choice is the total arrangement or organisation of a person's activities which will be held during a person's lifetime.

Wood [7] describes human communication as a way by which people share their ideas and thoughts in the form of symbols to bring out meaningful interpretations. Hybel and Weaver [8] explain that communication deals with the sharing of information, the emotions either in the form of written words, nonverbal or verbal which add understandings to the message. Communication is not static but is a two-way process of sharing ideas, information, and feelings from one person to another.

It can be argued that communication takes place in every facet of human lives and in all areas of human endeavours, especially in career and decision making. Career choice is an aspect of an individual's life that is very important which can build or ruin one's life. A career choice is an important decision because it impacts on the quality of a person's life. Career decisions also influence the degree of success and joy which a person achieves during his/her lifetime. Oluwagbemi, et.al. [9] are of the view that a good career path can promote quality of life, create sufficient income, and influence the social and economic sphere of any nation. A career choice frequently depends on the secondary school attended by learner Ferry [10]. He further opines that major crossroads in peoples' lives were experienced when they had to make decisions in high school. Shahzad, et.al. [11] affirm that students make career decisions while in high schools. Career choice is a phenomenon that looks simple and admirable, but in most cases, it proves to be very challenging. Many people become victims of circumstances simply because of incorrect career choice. Farheen and Saba [4] state that the choice of an appropriate career is very significant for any person, but an incorrect career choice can lead to various problems in the long run. Pavlina [12] indicates that it is extremely challenging to arrive at an accurate career choice even with deliberate and mindful introspection. Uwaifo [13] also maintains that if a career choice is not appropriately chosen, it may result in frustration and emotional pain which could ruin one's happiness for life. Salami and Salami [14] agree that the choice of career is a delicate matter that demands caution and serious attention.

Additionally, many high school students' find it very difficult to plan for their future or to decide what to choose as a pathway in life before entering the higher institutions of learning. Subsequently, they find it difficult to cope and this negatively affects their academic performance. This is one of the factors which contribute to high dropouts in the first year of university. The study conducted by Moodley and Singh [15] reveals wrong career choice as being the main factor that led to the dropout of students' in higher institutions of learning. Talib and Aun [16] state that one of the problems faced by young people is an undecided career option. This is a source of anxiety for many first-year students which could lead to a lack of confidence, lack of interest or academic failure during their course of study. An incorrect career choice is a contributing factor to the low level of employment in a society. Odo [17] indicates that an incorrect career choice contributes to spiralling unemployment rates. Uko and Achu [18] maintain that the process of making a career choice is a blueprint which people use for aiding gratifying employment opportunities and to design favourable lifestyles.

\section{Literature Review}

Every integral part of human activity is thrived by communication and life, without such, communication will be insignificant and human interaction will be empty. Rensurb and Angelopulo [19] note that communication is vitally linked to the success and effectiveness of human lives and it creates what they are, how they are perceived and how they perceive others. Majaro [20] opines that communication occurs in every walk of life including all areas of human endeavour. Morreale and Pearson [21] assert that communication is important in the growth of human beings. Communication facilitates human interaction, creates and develops friendships among people. Mersham and Skinner [22] observe that one of the most vital features of human existence focuses on the ability to connect with people through the use of verbal and non-verbal means of communication. Japp, et.al. [23] argue that communication performs a major function in career decision-making. In other words, without proper gathering of information from different angles through various media, worthwhile decisions may be impossible. Ince and Gul [24] affirm that communication is an inseparable part of human life which plays a vital role in all of human activities. This could be as a result of lack of communication. Ogundele and Feyisetan [25] argue that many graduates are jobless as a result of the wrong choice of career which are irrelevant to the needs and aspirations of the society. Moreover, the influence of wrong career choice has increased the number of unemployed people, robbers, troublemakers and hooligans among others. However, the need to understand the term communication is important. 


\section{Definition of Communication}

Communication is not static rather it is an act of sharing ideas, information, and feelings from one person to another. Pearson and Nelson [26] delineate communication as a process of transferring and having knowledge of a given information. Cleary, et. al. [27] describes communication as a process of transmitting messages or information through two or more people and trying to get a feedback about the interpretation of the information sent through different means, such as facial expressions, among others. Bearden, et.al. [28] describe communication as the term used in defining the method of exchanging ideas, information from the sender to the receiver of the information. Barrett [29] entitles communication as the conveyance of content from one person to another through verbal and non-verbal interactions. According to Samovar, et.al. [30], communication is a process which is not static; rather, it is a continuous activity which has an endless process. Communication is a two-way process of exchanging ideas, thoughts, feelings and information to people.

Steinberg [31] asserts that communication is a term applied to affect attitudes and opinions. Skinner, et.al. [32] describe communication as a method through which messages are packed, sealed off and transmitted by the sender towards the receiver via various channels in which the receiver is able to decode the message by giving a feedback to the sender. Communication is an act of exchanging information through a medium from a sender to a receiver. Cleary, et.al. [27] reveal that the term communication originated from a Latin word known as communicare, which means 'to make common'. They further opine that when communication takes place a mutual understanding is formed. Altinoz [33] defines communication as a collective method which allows continuous transfer and free-flow of information from one person to another. Communication is therefore a process of using words, signs and sounds to express comprehensible ideas and thoughts to someone else.

Communication is the process of transmitting information from one place to another. Emmitt [34] is of the opinion that communication is the method of obtaining all important information, understanding and successfully spreading the information to other relevant parties. Wood [7] perceives communication as an organised method in which individuals inter-relate with one another through the use of symbols to develop and interpret meanings. Having made a brief attempt at the definitions of communication from various scholars, communication can be said to mean transmission of messages from a sender to a receiver with a view to reaching a mutual understanding.

\section{Functions of Communication}

The significance of communication cannot be overlooked and underestimated in life. Communication is used as a transaction to achieve our daily needs. The table below provides different perspectives which show the vital roles of communication in our daily routines.

Table 1. Functions of Communication

Banerji and Dayal (2005) [38] add that communication enables appropriate interaction amidst the organizational members and this can contribute to the achievement and success of the organization.

Densie (2005) [39] states that communication helps in building, sustaining and maintaining the community at large.

Goldfrab (2006) agrees that communication is an appreciated means required in any given society because it provides information to the society. To corroborate this assertion, Apata and Ogunrewo (2010) [40] affirm that communication brings development to the society through provision of "capacity building" and enabling the community.

Pearson et al. (2006:133) [35] explain that communication helps in building and developing relationship amidst people or one another.

Steinberg (2007:19) [31] believes that people need love and companionship. This can take place through communication from family, friends, people and co-operation among co-workers in an organization.

Steinberg (2007:20) [31] states that communication helps us in our decision making whether intentionally and unintentionally.

Ivy and Wahl (2009:50) [41] maintain that communication helps in creating mutual understanding and building harmony among people.

\section{Elements of Communication Process}

Human communication can only occur following the presence of certain elements which are needed. According to Mersham, et.al. [36], there are definite elements which form part of the important arrangement of human communication. It can be stated that communication process is characterised by various elements. Van der Walt, et.al. [37] opine that to create effective communication flow, all elements involved must work together in order to avoid misinterpretation of information. In this regard, communication scholars have identified basic components of communication. Dwyer [42] asserts that communication process involves seven various elements which include sender, message, channel or medium, receiver, feedback, environment or setting and noise thus interacting with one another. We can therefore deduce that communication elements are important for the free flow of communication and without them, the communication will be incomplete. DeVito [43] agrees that elements of communication are interconnected not separated. Every element in the communication process survives in affiliation to other elements and any changes occurring in the communication process affect the other elements. In other words, the various elements of communication work together to achieve the desired communication that takes place. The diagram below shows the flow of how communication takes place: 


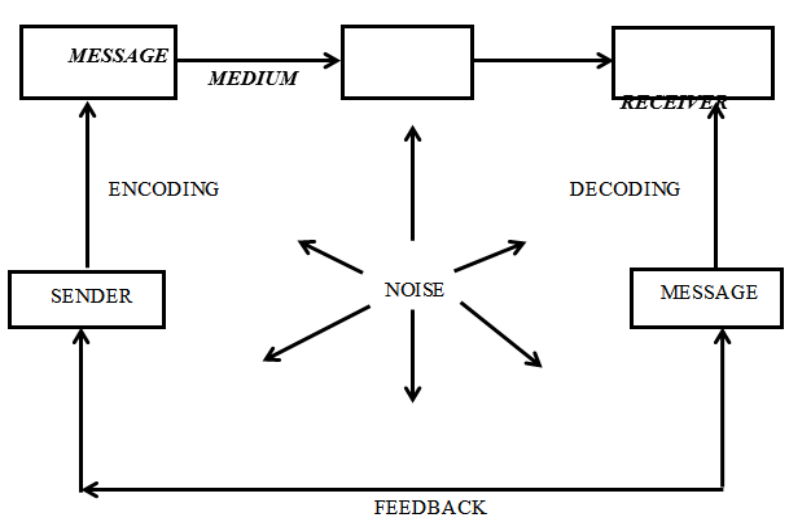

Source: Hartley and Bruckmann (2002:18) [44]

Figure 1. Elements of Communication Process

From figure 1, Van der Walt, et.al. [37] explain that the communication process begins with the sender who initiates the flow by encoding the message through communication and channel either verbally or non-verbally and sends to the receiver in order for him or her to decode the information transmitted. Seiler and Beall [45] state that communication source performs four roles known as: (1) determines the meaning of what is to be communicated, (2) encodes the meaning into a message, (3) sends the message (4) perceives and reacts to a listener's response.

DeVito [46] defines messages as indicators which serve as the motivation for the receiver including aural (hearing), optical (seeing), tactual (feeling), olfactory (smelling) and gustatory (tasting) stimuli. The message is in form of idea and thought which is to be communicated from one person to another. Van Riel [47] is of the opinion that the message should be in a clear form in order to enable the receiver to understand and interpret the information. Steinberg [31] states that the receiver in the communication process is the person to whom the message is sent through a vehicle which is called channel through which information passes before getting to the receiver. Examples of channels through which messages can be transmitted include face-face, emails, letters, billboards, memos and interviews with others. To corroborate this assertion, Pearson, et.al. [35] view that message can be conveyed through the use of words, facial expressions, body language and gestures in order to communicate ideas or piece of information.

In addition, Du Plooy-Cilliers and Louw [48] state that encoding is a reasoning method of transferring concepts into codes and expressing them into message while decoding is the procedure of taking both oral and non-verbal information received from the sender and giving it meaning. Pearson, et.al. [35] describe decoding as a method of ascribing meaning to the ideas or information received from the encoder.

Du Plooy-Cilliers and Louw [48] refer to feedback as "reply of a message which can be either verbal or non-verbal. It serves as a vital part of the communication process in that it notifies the sender to know whether the message has been decoded or not". Talukhaba, et.al. [49] argue that without feedback, communication is delayed, incomplete and ineffective. On one hand, communication between the sender and receiver may be interfered or hindered by noise. Smith [50] asserts that noise is anything which interrupts the flow of communication and creates a barrier between the sender and the receiver. Also, Steinberg [31] observes that noise is anything which disrupts the flow of information from the sender to the receiver.

\section{Channels of Communication in Career Choice}

There are different ways of communicating career guidance to high school learners so as to help them in their career decision. Kingazi [51] enumerates forms of communication in maintaining effective communication on career choice which includes newspaper, radio, television and magazines. Danaher and Rossiter [52] add that there are various forms of communication in order to guarantee effective communication such as television, radio, newspaper, internet, SMS and a host of others. However, there are different ways of communicating career choice to high school learners. These are: career orientation, career guidance, career day, social media, radio, among others.

\section{Career Orientation}

Career orientation as a channel of communication focuses on awareness of career choice in relation to various occupations available to the human race through individuals' special skills. Ryynänen [53] defines career orientation as an individual's approach towards certain specialized occupations. A research conducted by Nikolaou [54] on the role of career orientations shows that career orientation programmes have contributed positively to learners on their awareness about career choice. It also improves their abilities and skills required for various occupations. Career orientation creates awareness and provides information on career choice to students. In addition, Kariuki [55] observes that information received from high school through career orientation can assist many learners in making correct career choice and pursuing better future in life

Gerber, et.al. [56] affirm that career orientations are guides which influence individuals' career decision making and also show their desire to pursue specific occupations. Ari [57] agree that career orientation is very important because it helps in addressing individual's special skills. Lami and Mile [58] are of the view that career orientation is one of the factors which guides individual personal choices in life. Thus, career orientation is a channel of communication which is essential because it assists and guides students to identify their abilities and ensure that they make right career decisions. Milloshi [59] indicates that career orientation creates an educational 
environment for learners by providing them with appropriate information on various careers and also helps them to recognize their physical, intellectual and personal qualities. Wiroterat [60] maintains that career orientation creates career awareness for learners and also improves their level of information and skills on career choice which tends to impact their lives positively. Career orientation provides information on various occupations to students and ensures that such students make well informed decision which will ensure better future for them.

\section{Career Guidance}

Career guidance is a form of communication which simply means career assistance for a right career decision. Niles and Bowlsbey [61] assert that career counsellors help learners to develop career choice skills, self-awareness, job awareness and implement their awareness by making right career decisions. Zunker [62] states that learners receive appropriate career guidance from school which enhances their career decision-making for the future. Career guidance is a channel of communication which assists and guides students in their career decision making. Rosenbaum and Person [63] note that school career counsellors provide career intervention in schools with the goal of giving guidance, career information and academic advice to learners. Wadsworth, et.al. [64] state that career counsellors are professionals / trained personnel who specialise in the psychological perception of people by offering several services to them. Career counsellors are professionals who offer career guidance to students and help them in their choice of career. According to Rashid [65] career counsellors provide academic advice, career direction, develop career interest, career plan and help learners in making right career decisions about their future. $[64,66]$ state that career counsellors help learners to sustain their interest beginning from their early stage of schooling and this serves as a strong predictor in their career decision. Career counsellors play significant roles in students' career decision because they provide career information to students, encourage them and assist them in making right career choices. Sari [67] believes that career counselling is an essential part of the educational system because it provides valuable assistance to learners in their career decision-making phase. He further states that career counsellors who are liable to function as school counsellors play important roles by providing suitable career information to learners, encouraging career goals and presenting career opportunities to learners in all fields of work.

\section{Career Day}

Career day as a means of communication is a programme which is used by institutions of learning to communicate career guidance and provide career information to high school learners on career choice. Ref. 68 explain that career day creates opportunities for learners to associate with one another and it helps them to learn about their career path, the academic requirement for each occupation and the functions of each job. Kingazi [51] states that career day is a programme which assists learners in gathering important and necessary information needed in making career decision. Ref. 69 observes that career day gives learners the ability to experience university environment and also helps them to evaluate whether the value of a degree outweighs the fee. This study shows that career day helps most universities to transmit career information to students and also assists the universities to increase their enrolment for each field of study.

\section{Social Media}

Social media as a vehicle of communication refers to sources of online information formed, distributed and used by people in order to educate one another about certain information and products found accessible in the marketplace Murugesan [69]. Kaplan and Haenlein [70] describe social media as the accumulation of internet-based operation that is formed on theoretical and technical basics of Web 2.0 which authorises the formation and exchange of user-generated content. Papacharissi [71] states that social media serves as a source of information for users seeking information on various careers. Social media is a useful channel of communication to the publics. Williams, et.al. [72] affirm that social media is a channel of communication which helps users to access thousands of information as well as communicate with people all over the world in order to get assistance when making their career choices. Social media is a platform for communal interaction and also a channel of communication for sharing knowledge and career information to its users. Temmel [73] emphasises that social media is an important channel of communication on career information and awareness to users, such as learners.

\section{Radio}

Radio has been a medium of communication for many decades. Souleymane and Kadiatou [74] opine that radio is an essential form of communication which is used in transmitting information and ideas to members of the public and also changes the mindset of people in their career decision-making. Thus, radio is a channel of communication which is used in transmitting ideas, thoughts and opinion to the listeners. According to Servaes [75], radio is a form of communication which is universal, handy and affordable. Anifowose [76] observes that radio is a form of communication used by professionals in disseminating important information on various careers to mostly rural people in order to improve their career choices. From the scholars, it is believed that radio is a channel of 
communication which educates, transfers information such as career information and also entertains listeners

\section{Television}

Television is a telecommunication system where images of objects are transmitted. Saglik and Ozturk [77] assert that television is an effective device used in expressing theoretical ideas. Duncan [78] posits that television is a medium of communication which is active and significant in disseminating information such as career awareness to people through dramatic audio and visual manner. Television is a powerful persuasive form of communication which attracts large number of viewers. Valkenburg [79] argues that television is viewed by young people for pleasure as well as acquiring educational information on several available careers which guide their career decisions.

Mahmood and Sheikh [80] add that television serves an important role in awareness creation and information provision about career choice to people. Hoffner, et.al. [81] note that television has become an essential form of communication for young people because it provides various careers and job information. A study carried out by Soria, et.al. [82] using 105 respondents among second-year university students from Faculty of Medicine at the University of Zaragoza (Spain) shows that 11 percent of the respondents took a decision to study medicine as a result of the information acquired through television. Television is an important channel of communication because it creates awareness to the public and also transmits information on various occupations to a large audience.

\section{Newspapers}

Newspapers are regarded as daily or weekly publication on folded sheets made available for knowledge transmission to the public. $[83,84]$ add that newspapers are available in order to publicize various kinds of information (including career information) for the public to read and know them. Furthermore, Hussain [85] declares that newspapers are used in disseminating information on diverse issues including career decision. Igbeka and Christopher [86] assert that newspapers are among the most widely read reviews which provide latest information on local, state/provincial, national and world matters to the public. Thus, newspaper can be viewed as a channel of communication used in disseminating information including career information in order to assist students in their career decision.

\section{Research Methodology}

The survey is quantitative in nature. Quantitative method was used in the study. This allowed for large data collection in order for the researchers to be able to generalize results where possible and necessary. Kumar [87] states that adoption of quantitative method in a research allows for the collection of huge data which gives room for its generalization. The study adopted the purposive and random sampling techniques. For instance, while the universities were selected purposively, the participants which were first year from two South African universities were selected randomly. The two universities were selected purposively following their nature and location. Whilst the University of Zululand (UNIZULU) is comprehensive in nature, Durban University of Technology (DUT) as its name implies it is a technology-based institution of higher learning. The two universities are located in KwaZulu-Natal, northern South Africa. Also, while University of Zululand (UNIZULU) is situated in a rural environment, Durban University of Technology (DUT) is situated in an urban area. This gave the researchers the opportunity to survey the view of both rural and urban university students the various forms of communication adopted for disseminating career guidance services to them. Conversely, first year students were selected for this study because they are considered to be more prone to facing challenges with regards to career choices compared to other levels following the works of Boo and Kim [98], Uleanya, et.al.99], and especially Ackermann, et.al. [100] who are of the opinion that choice of career is a major area of concern for young people, especially those approaching the end of secondary school education and in search of tertiary qualifications in order to build their careers.

Sequel to the information retrieved about the number of registered first year students in the selected universities as at the time of this study, 374 first year students: 187 from each of the universities were randomly selected across all faculties in the two institutions. The total number of 374: 187 from each of the universities based on Du Plooy [101] sampling population table is shown below.

\begin{tabular}{|c|c|}
\hline \multicolumn{2}{|c|}{ Population size } \\
\hline Infinity & 384 \\
\hline 500,000 & 384 \\
\hline 100,000 & 384 \\
\hline 50,000 & 381 \\
\hline 10,000 & 370 \\
\hline 5,000 & 357 \\
\hline 3,000 & 341 \\
\hline 2,000 & 322 \\
\hline 1,000 & 278 \\
\hline
\end{tabular}

Source: Du Plooy (2009:119)

In addition, a self-designed questionnaire was used for data collection. The questionnaire contained two sections. Section A, contained questions which targeted at retrieving respondents' demographic information: gender and year of 
study. Section B contained questions focused on collecting information on forms of communication for disseminating career guidance services to them. The questions were developed following the objective of the study. The questions sought to know how the students received information regarding career choices. Attached to each of the questionnaire was a consent form and the information sheet. This was done to ensure that respondents voluntarily agreed to participate in the study. Both the researchers and the respondents had to sign the consent form. The information sheet contained guidelines on how the questionnaire was to be completed. This was done to clarify to the respondent the rationale behind the questionnaire. Meanwhile, a pilot study was conducted using 10 first-year students in one of the selected universities in order to provide dependable and valuable information when gathering data from the questionnaire. The researchers ensured that the students who participated in the pilot study were not selected for the actual research. The collected data from the questionnaire were analysed using frequencies and percentages by means of MoonStats software.

\section{Findings and Discussion}

The results of the analysed data are as presented below: Demographic information of students in UNIZULU and DUT

Table 2. The demographic profile of students in UNIZULU and DUT

\begin{tabular}{|c|c|c|c|c|}
\hline & \multicolumn{2}{|c|}{ UNIZULU } & \multicolumn{2}{c|}{ DUT } \\
\hline & $\begin{array}{c}\text { Frequency } \\
(\mathrm{N}=187)\end{array}$ & Percent & $\begin{array}{c}\text { Frequency } \\
(\mathrm{N}=187)\end{array}$ & Percent \\
\hline GENDER & & & & \\
\hline Male & 70 & 37.42 & 79 & 42.25 \\
\hline Female & 117 & 62.57 & 108 & 57.78 \\
\hline YEAR & & & & \\
\hline First year & 174 & 93.05 & 182 & 97.33 \\
\hline Repeating year & 13 & 6.95 & 5 & 2.67 \\
\hline
\end{tabular}

\section{Comparison of demographics information of students in UNIZULU and DUT}

This table provides the demographic information of respondents who participated in this study. The following variables (Gender and Year of study) formed part of the respondents' profile. The 172 (93\%) of the respondents who participated were mostly first-year students from UNIZULU. Likewise, the majority of participants: 180 $(97 \%)$ in DUT were mainly first-year students. Reason, et.al. [88] were of the view that the first year at the higher education of learning is a precarious year which serves as the basis for consecutive years of study at the university. The analysis further showed that $63.24 \%$ of the respondents were females while $37.8 \%$ males from UNIZULU. Similarly, $57.30 \%$ of the respondents from DUT were females while $43.7 \%$ remained the males. The study conducted by Sikwhari [89] revealed that when comparing male and female students at the higher education of learning in relation to academic attempts, females are more academically driven than males.

\section{FORMS OF COMMUNICATION TO POTENTIAL UNIVERSITY STUDENTS IN UNIZULU AND DUT}

Table 3 below contains 13 statements on the forms of communication for career guidance to potential university students in UNIZULU and DUT. In this section, the opinion of the respondents was rated on a three-point scale from 1 to $3,(1=$ Yes, $2=$ No and $3=$ Not sure $)$.

\section{Comparison of various forms of communication for career guidance services to potential university students in UNIZULU and DUT}

Table 3 describes the various forms of communication used in disseminating career services to potential university students in UNIZULU and DUT. In a comparison to the findings, there were similarities between two universities on the various forms of communication. The related variables include $1,3,6,9$ and 12 with their ranks as $1,6,11,7$ and 4 respectively. 
Table 3. Forms of communication used in disseminating career guidance in UNIZULU and DUT

\begin{tabular}{|c|c|c|c|c|c|c|c|c|c|c|c|}
\hline \multirow[b]{2}{*}{ NO } & \multirow[b]{2}{*}{ Forms of communication in } & \multicolumn{5}{|c|}{ UNIZULU } & \multicolumn{5}{|c|}{ DUT } \\
\hline & & Yes & No & $\begin{array}{l}\text { Not } \\
\text { Sure }\end{array}$ & $\begin{array}{l}\text { Mean } \\
\text { Score }\end{array}$ & Rank & Yes & No & $\begin{array}{l}\text { Not } \\
\text { Sure }\end{array}$ & $\begin{array}{l}\text { Mean } \\
\text { Score }\end{array}$ & Rank \\
\hline 1. & $\begin{array}{l}\text { I realised most of my career } \\
\text { information from my friends. }\end{array}$ & 40 & 139 & 8 & 1.83 & 1 & 63 & 69 & 55 & 1.96 & 1 \\
\hline 2. & $\begin{array}{l}\text { I acquired most of my career } \\
\text { information from my family. }\end{array}$ & 56 & 121 & 10 & 1.75 & 2 & 83 & 71 & 33 & 1.73 & 9 \\
\hline 3. & $\begin{array}{l}\text { I acquired most of my career } \\
\text { information from the internet. }\end{array}$ & 137 & 46 & 4 & 1.29 & 11 & 126 & 10 & 51 & 1.60 & 11 \\
\hline 4. & $\begin{array}{l}\text { I got hold of most of my career } \\
\text { information from career resources } \\
\text { library. }\end{array}$ & 93 & 87 & 7 & 1.54 & 9 & 97 & 84 & 6 & 1.51 & 12 \\
\hline 5. & $\begin{array}{l}\text { I received most of my career } \\
\text { information from visiting } \\
\text { professionals. }\end{array}$ & 71 & 106 & 10 & 1.67 & 5 & 42 & 120 & 25 & 1.91 & 3 \\
\hline 6. & $\begin{array}{l}\text { I got most of my career information } \\
\text { from career seminars and workshops. }\end{array}$ & 69 & 109 & 9 & 1.68 & 4 & 42 & 122 & 23 & 1.90 & 4 \\
\hline 7. & $\begin{array}{l}\text { I achieved most of my career } \\
\text { information from my school } \\
\text { teachers. }\end{array}$ & 104 & 82 & 1 & 1.45 & 10 & 140 & 35 & 12 & 1.32 & 13 \\
\hline 8. & $\begin{array}{l}\text { I attained most of my career } \\
\text { information from my school career } \\
\text { adviser. }\end{array}$ & 86 & 96 & 5 & 1.57 & 9 & 62 & 89 & 36 & 1.86 & 5 \\
\hline 9. & $\begin{array}{l}\text { I received most of my career } \\
\text { information from annual university } \\
\text { open day. }\end{array}$ & 83 & 90 & 14 & 1.63 & 7 & 93 & 48 & 46 & 1.75 & 7 \\
\hline 10. & $\begin{array}{l}\text { I received most of my career } \\
\text { information from university } \\
\text { prospectus. }\end{array}$ & 87 & 90 & 10 & 1.59 & 8 & 41 & 119 & 27 & 1.93 & 2 \\
\hline 11. & $\begin{array}{l}\text { I collected most of my career } \\
\text { information from the occasional } \\
\text { university adverts on the radio. }\end{array}$ & 69 & 109 & 9 & 1.68 & 4 & 56 & 121 & 10 & 1.75 & 8 \\
\hline 12. & $\begin{array}{l}\text { I got most of my career information } \\
\text { from the occasional university } \\
\text { adverts on the television. }\end{array}$ & 74 & 105 & 8 & 1.65 & 6 & 67 & 84 & 36 & 1.83 & 6 \\
\hline 13. & $\begin{array}{l}\text { I obtained most of my career } \\
\text { information from the occasional } \\
\text { university adverts in the newspaper. }\end{array}$ & 71 & 100 & 16 & 1.71 & 3 & 75 & 94 & 18 & 1.70 & 10 \\
\hline
\end{tabular}

The first form of communication referred to students receiving their career information through their friends. This finding coincides with the finding of the work of Witko, et.al. [90] which showed that many young people felt more comfortable approaching their friends on career information before making career choices compared to meeting their parents and teachers. Meanwhile, according to Mukwevho [91], one of the challenges faced by learners is the non-availability of mentors and supervisors such as parents, family and teachers. Suffice to state that learners are likely to approach their friends more for career guidance based on their availability.

The second form of communication used in communicating career information to potential university students between the two universities was the internet. This finding agrees with the work of $[92,93]$ who explained that people made use of the internet to acquire information on their career decision. In congruence to this finding, Williams, et.al. [72] stated that the internet is a form of communication tool which assists users in accessing information on various opportunities especially on career choices as well as communicating with other people all over the world. In support of this, Hooley, et.al. [94] observed that sites on the internet such as career blogs and others create an effective and efficient method of on career information and development. This finding implies that the internet is a major communication tool which is to be adopted by young people before reaching a career choice decision where necessary.

The third form of communication used for career guidance services to potential university students in the two universities was the use of career seminars and workshops. This finding agrees with the work of Jones and Larke [95] who opine that career seminar assists young people in their career decision because it increases their career information and exposure. The finding also corroborates the finding of the research conducted by Nikolaou [54] which shows that career seminars, workshops and programmes contribute positive impacts on the learners through the provision of relevant career information which is needed for various occupations that are available to them. Moreover, following the work of Wiroterat [60] career 
seminars and workshops create career awareness for learners and also improve their levels of information and skills on various careers which are envisaged to eventually impact positively on their lives. Suffice to state that seminars, workshops and other related relevant programmes are capable of furnishing young people with the necessary information needed to guide them to reach the right decisions in their choice of career.

The fourth form of communication agreeable to the two universities is the use of the open day. This finding agrees with the work of Hughes and Karp [96] who opine that career guidance services such as open day are an effective way because it contributes positively to the awareness of career information, consequently, career decisions. In congruence to this finding, Ososki, et.al. [97] opine that open day assists learners to pursue their dreams through the information gathered. Meanwhile, Macera and Cohen [68] argue that open day creates opportunities for learners to associate with one another and helps them to learn more about their career path, the academic requirement for each occupation and the functions of each job. This finding implies that university open day is expected to be crucial to learners as it affords them the opportunities of meeting other learners, getting relevant career related information by asking relevant questions from experts.

In addition, the fifth form of communication agreed upon by students from the two universities is through occasional university adverts on the television. This finding concurs to the work of Valkenburg [79] who avers that television is watched by young people for enjoyment as well as acquiring educational information on several available careers capable of guiding them in making informed career decisions. The finding also coincides with the work of Mahmood and Sheikh, [80] who state that television serves an important role in awareness creation and provision of information about career choice to people. Meanwhile, in support of this, Hoffner, et.al. [81] noted that television has become an essential form of communication for young people because it provides various career and job information. However, in contrast to this finding, Ryynänen [53] opines that radio is a relevant tool adaptable for communicating career opportunities to learners. This finding suggests that television is integral to providing relevant career information to learners, similarly, radio as well.

On the contrary, there was a difference between the opinions of UNIZULU and DUT students on the various forms of communication for career guidance services to potential university students in statement $2,4,5,7,8,10$, 11 and 13 . The mean rating and the rank for these variables were at variance.

In brief, the findings of the study indicated that students in both universities believed that friends, internet, career seminars and workshops, university open day, and the television were the major channels of communication that disseminate career guidance services to potential university students. Meanwhile, Ryynänen [53] add that there are various forms of communication which can be used to guarantee effective communication and also disseminate career awareness to people such as television, radio, newspaper, internet and SMS. Suffice to state that the main adopted forms of communication for disseminating career guidance services in the selected South African universities are: friends, internet, career seminars, career workshops, university open day, television. However, radio, newspaper and SMS are other valuable forms of communication for disseminating career guidance services that can be adopted.

\section{Conclusion and Recommendations}

The researchers explored the various forms of communication for disseminating career guidance services to potential university students. Selected first year students from the University of Zululand (UNIZULU) and Durban University of Technology (DUT) were adopted for the study. The collected data were analysed and compared following the responses of the respondents from the two selected South African universities. Based on the findings, the students from DUT were more aware of various careers that are available in the country. They have access to good career information that can provide students with a stable and secure future, careers that pay well and also collaborative opportunities with successful people in various careers. On the contrary, most of the students that participated in this study from UNIZULU are not well-informed about careers that are available in the country. However, the channels of communication that have helped the first-year students in both DUT and UNIZULU in getting to know the information on career choices were friends, internet, career seminars, workshops, university open day and television. Sequel to the findings of the study, the following recommendations are made:

Universities should organize orientation programmes to assist students with career choice before registration. This could be accomplished through the use of peer counsellors and faculty staff who could inform prospective students from feeder schools about the various possibilities that exist.

Universities should advertise their courses through various forms of communication to the potential, prospective university students so as to reduce doubts and transfer from one course to another in their first year of study.

It will be of help if the universities can offer a course on career development which will provide students with the necessary career awareness and assist the students in real-life experience opportunities in the form of apprenticeships, work integrated learning and work place learning.

It is recommended that various career awareness programmes should be organised for students regularly, in 
an endeavor to empower them to make knowledgeable choices. Moreover, student orientation, career and support programmes should be made available by the university in order to assist the incoming students to cope with university life. Such programmes can be in form of career seminars and workshops. This will assist students in being abreast of available career information before making career decisions.

Since the family is believed to be the first unit of socialization and parents play vital roles in influencing their children, hence, they should be more informed and enlightened on career information. This will enable them to assist their children in their career decision processes by giving sound counselling and not by forcing them to go for careers contrary to their interest and abilities.

\section{REFERENCES}

[1] W. Arens, D. Schafer, F. Weigold. Advertising. McGraw-Hall, New York, 2012.

[2] Chatterjee, I, Importance of Communication. Online available from http://www.buzzle.com/articles/importanceof-communication

[3] McLaughlin M, The Ultimate Political Animal, Online available http://www.ashbrook.org/publicat/mclaughlin.html

[4] B. Farheen, I. Saba, Impact of career selection on job satisfaction in the service industry of Pakistan. African Journal of Business Management, Vol.6, No.9, 3384-3401

[5] J. Greenhaus. Handbook of Psychology: Career dynamics. John Wiley and Sons, Hoboken, 2003.

[6] M. Natalie, Factors influencing career choice among high school students' in Tanzania. Journal of Dental Education, Vol.64, No.6, 423-429.

[7] J. Wood. Communication in our lives. $7^{\text {th }}$ Ed. Wadssworth, Toronto, 2014.

[8] S. Hybel, R. Weaver. Communicating Effectively. 7th Ed. McGraw-Hall, New York, 2007.

[9] O. Oluwagbemi, M. Adebiyi, S. Fatumo, G. Macintyre. Paving the Way towards a Successful and Fulfilling Career in Computational Biology. Journal of Computational Biology, Vol.10, No.5, 1-3.

[10] N. Ferry. Factors influencing career choice of adolescents and young adults in rural Pennsylvania. Journal of Extention, Vol.44, No.3, 1-6.

[11] M. Shahzad, S. Zahra, M. Ahme. Determinants and Influences on Students' Career Choice. Universal Journal of Management and Social Science, Vol.4, No.3, 9-30.

[12] Pavlina, S, The challenges of choosing the right career, Online available from http://www.stevepavlina.com/blog/2 007/11/the-challenge-of-choosing-the-right-career/

[13] Uwaifo, V, Career choice amongst Nigerian University entrants: factors that count, Online available from http://www.globalacademicgroup.com.

[14] O. Salami, O. Salami. The Factors Determining the Choice of Career among Secondary School Students'. The International Journal of Engineering and Science, Vol.2, No.6, 33-44.

[15] P. Moodley, R. Singh. Addressing Student Dropout Rates at South African Universities. Alternation journal for the Study of the Arts and Humanities in Southern Africa, Vol. 17, 91-115.

[16] A. Talib, T. Aun. Predictors of career indecision among Malaysian undergraduate students. European Journal of Social Sciences, Vol. 8, 215-224.

[17] M. Odo. Sustaining occupational information for career choice and development in students of technical colleges in Enugu state, Nigeria. Journal of Technical Education and Training, Vol.7, No.1, 4.

[18] S. Uko, A. Achu. Templates That Determines the Choice of Course Selection in the University: A Case Study of University of Calabar. Journal of Emerging Trends in Educational Research and Policy Studies, Vol.4, No.2, 246-251.

[19] R. Rensurb, G. Angelopulo. Effective Communication Campaign. Thomas Publishing Cape Town, 2000.

[20] S. Majaro. The Essence of Marketing. Prentence Hall, Tohenhan, 1993.

[21] S. Morreale, J. Pearson. Why Communication Education is important: The Centrality of the Discipline in the $21 \mathrm{st}$ Century. Communication Education, Vol.57, No.2, 224-240

[22] G. Mersham, C. Skinner. New Insights into Communication and Public Relations. Heinemann Higher and Further Education, Johannesburg, 2002.

[23] P. Japp, M. Meister, D. Japp. Communication ethics, media, and popular culture. Peter Lang, New York, 2005.

[24] M. Ince, H. Gul. The role of organizational communication on employees' perception of justice: A sample of public institution form Turkey. Journal of Social Sciences, Vol.21, No.1, 106.

[25] A. Ogundele, C. Feyisetan. Impact of Vocational Guidance in Addressing the Choice of Vocational and Technical Education among Nigeria Youth. Open Science Journal of Education, Vol.2, No.5, 56-60.

[26] J. Pearson, P. Nelson. An introduction to human communication: understanding and sharing. McGraw-Hill, Boston, 2000.

[27] S. Cleary, M. Harran, J. Luck, S. Potgieter, E. Scheckle, R. Merwe, K. Heerden. Communication a Hands-on Approach. Juta \& Company Ltd, South Africa, 2008.

[28] W. Bearden, T. Ingram, R. LaForge. Marketing: Principles and Perspectives. 4th Ed. McGraw-Hill/Irwin, New York, 2004.

[29] D. Barrett. Leadership communication. McGraw Hill, Boston, 2006.

[30] L. Samovar, R. Porter, E. McDaniel. Communication 
between Cultures. 6th ed. Thomson Wadsworth, Canada, 2007.

[31] S. Steinberg. An Introduction to Communication Studies. Juta and Company Ltd, Cape Town, 2007.

[32] C. Skinner, L. Von Essen, G. Mersham, S. Motau. Handbook of Public Relations. 7th ed. Oxford University Press, South Africa, 2007.

[33] M. Altinoz. An overall approach to the communication of organizations in conventional and virtual offices. International Journal of Human Social Sciences, Vol.4, No.3, 218-223.

[34] S. Emmitt. Managing interdisciplinary projects: a primer for architecture, engineering and construction. Spon Press, London, 2010.

[35] J. Pearson, P. Nelson, S. Titsworth, L. Harter. Human Communication. 2nd Ed. McGraw-Hill, New York, 2006.

[36] G. Mersham, R. Rensburg, C. Skinner. Public relations, development and social investment: A southern African perspective. Van Schaik, Pretoria, 1995.

[37] A. Van der Walt, J. Strydom, S. Marx, C. Jooste. Marketing management. 3rd Ed. Juta, Kenwyn, 1996.

[38] A. Banerji, A. Dayal. A study of communication in emergency situations in hospitals. Journal of Organizational Culture, Communications and Conflict, Vol.9, No.2, 35-45.

[39] Densie, R, The Art of Communication. Online available from www.indiancountflcomcontent.ctm.

[40] T. Apata, J. Ogunrewo. Analysis of Traditional Information Dissemination and Communication Method among Rural Farmers. Evidence from Traditional Communities in Nigeria. Montpellier: Scientific and Technical Information and Rural Development IAALD XIIIth World Congress

[41] D. Ivy, S. Wahl. The nonverbal self: Communication for a lifetime. Allyn and Bacon, Boston, 2009.

[42] J. Dwyer. Communication for Business and the Professions: Strategies and skills. French's Forest. Pearson, Australia, 2005.

[43] A. DeVito. Essential of human communication. 8th Ed. Pearson, New York, 2013.

[44] P. Hartley, C. Bruckmann. Business Communication. Routledge, London, 2002.

[45] W. Seiler, M. Beall. Communication: Making Connections. 8th Ed. Allyn \& Bacon, Boston, 2011.

[46] J. DeVito. The Interpersonal Communication Book. 9th Ed. Longman, New York, 2001.

[47] C. Van Riel. Corporate Branding Management. Journal of Management, Vol.4, 12-16.

[48] F. Du Plooy-Cilliers, M. Louw. Interpersonal Communication. 2nd ed. Heinemann Educational Publishers, Cape Town, 2003.

[49] A. Talukhaba, T. Mutunga, C. Miruka. Indicators of effective communication models in remote projects. International Journal of Project Organization and Management, Vol.3, No.2, 127-138.
[50] R. Smith. Strategic Planning for Public Relations. Lawrence Erlbaum 6 Associates Publisher, London, 2005

[51] S. Kingazi. Kiswahili and African Indigenous Languages for Sustainable Development in Tanzania: The Case of Western Usambara. Masters Mini-Dissertation, Unpublished. IDS. Tanzania: University of Dar es Salaam, 2006.

[52] P. Danaher, J. Rossiter. Comparing perceptions of marketing communication channels. European Journal of Marketing, Vol.45, No.1/2, 6-42.

[53] K. Ryynänen. Constructing physician's professional identity - explorations of students' critical experiences in medical education (Doctoral dissertation). Oulu: University of Oulu, 2001.

[54] G. Nikolaou. The university tutorial: Greek students' development of intercultural competences. Journal of Revista Interuniversitaria De Formación Del Profesorado, Vol.22, No.1, 165-184.

[55] Kariuki, K. An Easy to Read guide on Careers. Online available from http// www.Sunday Nation.com.

[56] M. Gerber, A. Wittekind, G. Grote, B. Staffelbach. Exploring types of career orientation: a latent class analysis approach. Journal of Vocational Behavior, Vol.75, No.3, 303-318.

[57] E. Ari, F. Vatansever, A. Uzun. Student professional orientation using fuzzy logic rules and quality. 6th Research/Expert Conference with International Participations. 'Quality, 4-7 2009.

[58] R. Lami, K. Mile. Neoliberalism effects in Albanian higher education. Journal of International Academic Research for Multidisciplinary, Vol.11, 487- 494.

[59] M. Milloshi. How to improve the performance of high school education in the city of Durrës and to cultivate a more critical thinking at the students. 1st Albania International Conference on Education (AICE) Tirana: Epoka University, 2013.

[60] W. Wiroterat. Dynamic audit knowledge and audit success of CPAs in Thailand: an empirical investigation of the antecedents and consequences. International Journal of Business Strategy, Vol.1, 89-106.

[61] S. Niles, J. Bowlsbey. Career development interventions in the 21 st century. Merrill Prentice Hall, New Jersey, 2002.

[62] V. Zunker. Career Counselling: Applied Concepts of Life Planning. Pacific Grove, California, 2002.

[63] J. Rosenbaum, A. Person. Beyond college for all: policies and practices to improved transitions into college and jobs. Professional School Counselling, Vol.64, 252-260.

[64] J. Wadsworth, A. Milsom, K. Cocco. Career development for adolescents and young adults with mental retardation. Professional School Counseling, Vol.8, 141-147.

[65] A. Rashid, A. Bakar, S. Asimiran, L. Tieng. Career Development Interventions in Secondary Schools in the State of Terengganu, Malaysia European Journal of Social Sciences Vol.8, No, 1, 62 .

[66] J. Watters. Career Decision Making Among Gifted Students: The Mediation of Teachers. Gifted Child Quarterly, Vol.54, 


\section{No.3, 222-238}

[67] E. Sari. School Counsellors Education with Observation in Schools. Procedia Social and Behavioural Science, Vol.2, 3899-3903.

[68] M. Macera, S. Cohen. Psychology as a profession: An effective career exploration and orientation course for undergraduate psychology majors. The Career Development Quarterly, Vol.54, 367-371.

[69] S. Murugesan. Understanding Web 2.0. Journal of IT professional, Vol.9, No.4, 34-41.

[70] A. Kaplan. M. Haenlein. Users of the world, unite: The challenges and opportunities of social media. Journal of Business Horizons, Vol.53, No.1, 59-68.

[71] Z. Papacharissi, A. Rubin. Predictors of internet use. Journal of Broadcasting and Electronic Media, Vol.44, No.2, 175-196.

[72] D. Williams, V. Crittenden, T. Keo, P. McCarty. The use of social media: an exploratory study of uses among digital natives. Journal of Public Affairs, Vol.12, No.2, 127-136.

[73] Temmel, M. The Impact of the Internet on our Daily Life. Online available from http//www.tru.ca/cpi/essay.htmil.

[74] Souleymane, O. Kadiatou, O. From Information to Communication in Burkina Faso: The Brave New World of Radio. Online available from http://www.idrc.ca/openebook $\mathrm{s} / 224-4 /$.

[75] J. Servaes. Communication for Development and Social Change. Sage Publications, New Delhi 2008.

[76] B. Anifowose. Exploring Radio as a Means for Disseminating Development Messages. Department of Communication and Language Arts, University of Ibadan, Ibadan, 2013.

[77] M. Saglik, S. Ozturk. Television as an Educational Technology: Using Television at Open Education Faculty, Anadolu University. Turkish Online Journal of Distance Education-TOJDE. Vol.2, No.1, 6

[78] T. Duncan. IMC: Using advertising and promotion to build brands. McGraw-Hill, New York, 2002.

[79] P. Valkenburg. Children's responses to the screen: A media psychological approach. Lawrence Erlbaum Associates, Inc., Hillsdale, 2004.

[80] Mahmood, M. Sheikh, A. Crop yields from new technologies. Online available from http//www.Daily Dawn.com

[81] C. Hoffner, K. Levine, Q. Sullivan, D. Crowell, L. Pedrick, P. Berndt. TV characters at work: Television's role in the occupational aspirations of economically disadvantaged youths. Journal of Career Development, Vol.33, 3-18.

[82] M. Soria, M. Guerra, I. Giménez, J. Escanero. La decision de estudiar medicina: características. Journal of Educación Médica, Vol.9, No.2, 91-97.

[83] Flor, A. Information and communication opportunities for technology transfer and linkages. Online available from http://www.upou.org/downloads/out.html.
[84] E. Babalola. Newspapers as Instruments for Building Literate Communities: the Nigerian Experience. Nordic Journal of African Studies, Vol.11, No.3, 2-6

[85] M. Hussain. Mass media: Extension Methods. $3^{\text {rd }}$ ed. Islamabad, Pakistan, 2005.

[86] J. Igbeka, O. Christopher. Use of Newspapers by Nigerian University Students: The Case of Delta State University. Anwai: Library Philosophy and Practice, Delta, 2010.

[87] R. Kumar. Research Methodology: A Step-by-Step Guide for Beginners. SAGE Publications, Los Angeles, 2019.

[88] R. Reason, P. Terenzini, R. Domingo. First things first: Developing academic competence in the first year of college. Research in Higher Education, Vol.47, 149-175.

[89] T. Sikwhari. The relationship between affective factors and the academic achievement of students at the University of Venda. South African Journal of Higher Education, Vol.21, No.3, 520-536.

[90] K. Witko, K. Bernes, K. Magnusson, A. Bardick. Senior high school career planning: what students want. Journal of Educational Enquiry, Vol.6, No.1

[91] M.H. Mukwevho, Time Management Challenges on Students' Academic Performance: A Case Study of a Rural University in Limpopo Province, South Africa. AFFRIKA Journal of Politics, Economics and Society, Vol.8, No.2, 81-99.

[92] T. Wilson. Human information behaviour. Information Science, Vol.3, No.2, 49-55.

[93] J. DiMicco, D. Millen, W. Geyer, C. Dugan, B. Brownholtz, M. Muller. Motivations for social networking at work. In: Proc ACM 2008 conference on computer supported cooperative work. San Diego, 711-720

[94] T. Hooley. How the internet changed career: framing the relationship between career development and online technologies. Journal of the National Institute for Career Education and Counselling, Vol.29, No.1, 3-12.

[95] W. Jones, A. Larke. Enhancing the life for hispanic individuals through career preparation. Journal of Hispanic Higher Education, Vol.4No.1, 5-18.

[96] K. Hughes, M. Karp. School-Based career development: A synthesis of the literature. Institute on education and the economy. Teachers college: Columbia University, Columbia, 2004.

[97] A. Ososki, J. White, S. Morago, J. Van Sickle. Factors affecting science undregraduates choice of teaching as a career. A case study at Humboldt State University. Humboldt State University, California, California, 2006.

[98] S. Boo, S. Kim, Career Indecision and Coping Strategies among Undergraduate Students. Journal of Hospitality \& Tourism Education, Vol.32, No.2, 63-76,

[99] Uleanya, C. Uleanya, M.O. Oluyemi, S. Revisiting High School Teachers' Education. Cogent Social Sciences. Online Available from https://doi.org/10.1080/23311886.2019.165 3545

[100] C. Ackermann, C. Alberts, N. Mbalo, Adolescents' Perceptions of the Relevance of Domains of Identity 
Formation: A South African cross-cultural study. Journal of Youth and Adolescence, Vol.32 No.3, 169-84.
[101]G. Du Plooy. Communication Research: Techniques, Methods and Applications. 2nd Ed., Juta and Company Ltd., Cape Town, 2009. 